\title{
The effects of growth hormone treatment on lipid parameters
}

\author{
Süleyman Ersin ÜNLÜ* \\ Ankara Training and Research Hospital Pediatrics Clinic, Ankara, Turkey
}

\begin{abstract}
My objective in this study was to determine the effects of Growth Hormone on lipid parameters. This retrospective study was performed in Ankara Training and Research Hospital. Lipid parameters were followed in GH deficient patients and compared with the control groups. The data was analyzed by using the SPSS package program. Friedman and Kruskal-Wallis tests were used for the statistical analysis. In the first group of 27 patients who took treatment for at least a period of 18 months, 14 patients were male (51.9\%) and 13 female (48.1\%). For 20 patients who were recently diagnosed as GH deficient or were not taking any treatment, 15 were male $(75 \%)$ and 5 female $(25 \%)$. The groups were homogeneous for gender. There were no statistically significant differences in all parameters from the beginning to the 18 th month point. Changes were seen only in the first group, as average height increase in the first 6 months decreased from $5.6 \mathrm{~cm}$ ( \pm 1.5$)$ to $3 \mathrm{~cm}$ $( \pm 1)$ in the second 6 month and this was statistically significant.
\end{abstract}

\section{Introduction}

It has been known that Growth Hormone treatment has important beneficial effects on: body composition, bone metabolism and lipid metabolism [1,2]. In a study done by Keizer Schrama et al., it was shown that Growth Hormone decreased the levels of total cholesterol, Low density Lipoprotein and Apolipoprotein-B in 38 Growth Hormone deficient patients [3]. In a survey done by Kohno et al., it was also shown that Growth Hormone treatment for 9 months didn't differ total cholesterol level, however it increased High Density Lipoprotein cholesterol level [4].

Growth hormone (GH): GH is a mono-chain peptide hormone composed of 191 amino acids. Its gene complex is on the long arm of the 17th chromosome. Its secretion is controlled mainly by GH Releasing Hormone (GHRH) secreted from hypothalamus and somatostatin which is an inhibitor in character. Its secretion is pulsatile as pulsation frequency increases especially in sleep.

The effects of Growth hormone: GH stimulates Insulin-like Growth Factor (IGF-1) secretion (IGF-1: Somatomedin C) from the liver. This stimulates especially the linear growth of the bones. These factors mostly bind to insulin-like Growth Factor Binding protein-3 (IGFBP-3) in the circulation.

Growth Hormone has direct effects on carbohydrate and lipid metabolism. Carbohydrate intolerance in oral glucose test is observed in individuals who have GH deficiency. This effect is due to pancreatic islet hypoplasia and insulin deficiency in relation. Hypoglycemia develops when insulin is given to these patients [5].

The effects of Growth hormone on lipid metabolism: It is known for a long time that fat tissue is the target of Growth Hormone effect. In the $\mathrm{GH}$ deficient children, before the $\mathrm{GH}$ replacement treatment the average size and fat content of the subcutaneous fat cells are decreased. Paradoxically, the average size and fat content of the fat cells are more than normal. The average size and fat content of the adipocytes in the subcutaneous fat stores decreased after 6 months to 2 years GH treatment. This shows the effect of GH via the IGF-1.

GH decreases body fat by decreasing fat stores and mobilization. GH increases hydrolysis of triglycerides to free fatty acids and again decreases the amount of fatty acids converting to triglycerides. $\mathrm{GH}$ is a counter-regulatory hormone that antagonizes the hepatic and peripheral effects of insulin, on glucose metabolism via mechanisms involving the concomitant increase in FFA flux and uptake.

GH has 2 distinct effects, as a result of the metabolic effect cellular lipid content decreases and the number of fat cells increases by the effect of stimulation of growth. In some studies it was shown that GH treatment decreased atherogenic index which is computed as logarithm of triglyceride divided by HDL cholesterol value meaning [log (triglyceride/ HDL cholesterol)] [6-10].

Serum GH: GH secretion is affected from eating food; hyperglycemia suppresses the secretion, amino acids and hypoglycemia stimulates secretion. If GH deficiency is suspected, one of the stimulation tests must be applied.

The patients who had peak GH levels below 7 nanograms $/ \mathrm{ml}$ after the stimulation tests, are defined as complete GH deficient and between 7 and 10 nanograms/ml as partial GH deficient [5].

The other diseases causing growth retardation are as follows: skeletal dysplasia, chromosomal anomalies, primordial dwarfism, malnutrition, malabsorption, inflammatory bowel disease, chronic renal disease, cardiac diseases, central nervous system diseases,

Correspondence to: Dr. Süleyman Ersin ÜNLÜ, Family Physician, Koru district Şahin city-estate, B block No:5, Çayyolu-Yenimahalle, ANKARA, Turkey, Tel: 0-505-4757986; E-mail: drsuleymanersin@gmail.com

Key words: growth hormone, lipid parameters, atherogenic index

Received: February 09, 2016; Accepted: March 18, 2016; Published: March 21, 2016 
hematological diseases, diabetes mellitus, vitamin D resistant rickets, other metabolic diseases, hypopituitarism, isolated growth hormone deficiency, thyroid hormone deficiency, glucocorticoid excess, psychosocial dwarfism and constitutional growth retardation [5].

In our study we tried to evaluate the effect of Growth Hormone on lipid parameters whether it influences the routine biochemical markers or not, in a time period in Growth Hormone deficient pediatric patients who were diagnosed by the stimulation tests.

\section{Methods}

Patient selection: In our study there were 62 patients whom 47 of them (study group) had the diagnosis of GH deficiency and followed in the Ankara Training and Research Hospital Pediatrics Endocrinology Policlinics and 15 of them (control group) were patients applying to the pediatrics policlinic for any other complaints. 27 cases of the GH deficient patients had been taking treatment for at least 18 months (group 1). Whereas 20 cases were newly diagnosed who either had not been treated or just begun to treatment (group 2).

The patients in the study group were divided into 3 according to the GH peak response to stimulation tests and nocturnal $\mathrm{GH}$ levels: Complete GH deficiency (peak response: $<7 \mathrm{ng} / \mathrm{ml}$ ), partial GH deficiency (peak response: 7-10 ng/ml) and 6 neurosecretory dysfunction. GH was given in 0.7 units $/ \mathrm{kg} /$ week dose in pre-pubertal patients and 0.9 units $/ \mathrm{kg} /$ week doses in pubertal patients.

Methods: The dossiers of the patients having the diagnosis of GH deficiency and followed up in the pediatrics endocrinology policlinics were searched retrospectively. Lipid parameter values of these patients were recorded before beginning of the treatment and with 6 months intervals then. Serum cholesterol and triglycerides were determined in central laboratory of the hospital by IL 1800 (Instrumentation Laboratory) auto analyzer.

Statistical methods: With SPSS analysis program Pearson's 2-tailed correlation matrix was formed. For all the groups descriptive statistics (average and standard deviation) were performed. For intra-group significance search Friedman test was performed, and for the between groups significance search Kruskal-Wallis test was applied.

\section{Results}

In the first group of 27 patients who were treated for at least 18 months, 14 patients were male (51.9\%) and 13 female (48.1\%). For the 20 patients who were recently diagnosed as GH deficient or were not taking any treatment, 15 were male $(75 \%)$ and 5 female $(25 \%)$. The groups were homogeneous for gender $(p>0.05)$. The values of the first group who had taken treatment for at least 18 months are shown in the Tables 1-3.

The average age of the 20 patients in the second group who were newly diagnosed GH deficiency patients was 10.7 ( \pm 3.2$)$ years; the average body weight was $28.3( \pm 12.5) \mathrm{kg}$ and the average height was $125( \pm 18.4) \mathrm{cm} .16(80 \%)$ patients were complete GH deficient and 4 (20\%) patients were partial GH deficient. In 3 patients treatment was not started yet. 13 of the 17 patients were pre-pubertal so were given $\mathrm{GH}$ at the dose of 0.7 units $/ \mathrm{kg} /$ week and 4 patients were pubertal and were given $\mathrm{GH}$ at the 0.9 units $/ \mathrm{kg} /$ week dose.

For the comparison of the first group, second group and the control groups' beginning values Kruskal-Wallis variance analysis test was used.

The comparisons between the groups are demonstrated in the Tables 4 and 5 .

It is known that GH has effects on height increase and also metabolic effects. Its effects on protein, carbohydrates and lipid metabolism are still subjects of debate and research. The effects of GH on lipid metabolism and lipid profile are subject to many researches but results were inconsistent with each other $[3,7,9,10,11]$.

In a survey GH was given at the dose of 2 and $4 \mathrm{IU} / \mathrm{m}^{2} /$ day to

Table 1.The comparison of beginning, $6^{\text {th }}$ month, $12^{\text {th }}$ month and $18^{\text {th }}$ month Triglyceride, Total Cholesterol, LDL, VLDL, HDL Cholesterol values (intra-group comparisons)

\begin{tabular}{|c|c|c|c|c|c|c|c|c|c|}
\hline & \multicolumn{2}{|c|}{ Basal } & \multicolumn{2}{|c|}{$6^{\text {th }}$ month } & \multicolumn{2}{|c|}{$12^{\text {th }}$ month } & \multicolumn{2}{|c|}{$18^{\text {th }}$ month } & \multirow[b]{2}{*}{ p } \\
\hline & average & SD & average & SD & average & SD & average & SD & \\
\hline Triglyceride & 111.3 & 43.4 & 126.8 & 40.4 & 137.6 & 65.6 & 139.6 & 108.3 & $\mathrm{p}>0.05$ \\
\hline \multicolumn{10}{|l|}{ Total } \\
\hline cholesterol & 151.8 & 34.1 & 147.3 & 29.3 & 145.1 & 22.2 & 149.7 & 31.6 & $\mathrm{p}>0.05$ \\
\hline LDL & 70.5 & 7.8 & 58.5 & 9.2 & 69 & 2.8 & 56 & 32.5 & $\mathrm{p}>0.05$ \\
\hline VLDL & 22 & 8.5 & 25.1 & 8.3 & 27.3 & 13.2 & 28 & 21.7 & $\mathrm{p}>0.05$ \\
\hline HDL & 49.5 & 3.5 & 56.5 & 6.3 & 50 & 12.7 & 64 & 19.8 & $\mathrm{p}>0.05$ \\
\hline
\end{tabular}

Table 2. Increase in height $(\mathrm{cm})$ for the first group in $6^{\text {th }}$ month, $12^{\text {th }}$ month and $18^{\text {th }}$ months.

\begin{tabular}{|l|c|c|c|c|c|}
\hline & $0-6$ Month* & & \multicolumn{2}{|c|}{$6-12$ Month* } & \multicolumn{2}{|c|}{ 6-12-18 Month } \\
\hline & average & SD & average & SD & \\
\hline Increase in & & 1.5 & 3 & 1 & 4.8 \\
\hline height & 5.6 & & & \\
\hline$* p<0.05$ & & & \\
\hline
\end{tabular}

Table 3. Comparison of BMI and AI of first group at the beginning, $6^{\text {th }}$ month, $12^{\text {th }}$ month and $18^{\text {th }}$ month.

\begin{tabular}{|l|c|c|c|c|c|c|c|c|}
\hline & Basal & & $\mathbf{6}^{\text {th }}$ month & & \multicolumn{2}{|c|}{$\mathbf{1 2}^{\text {th }}$ month } & \multicolumn{2}{|c|}{$\mathbf{1 8}^{\text {th }}$ month } \\
\hline & average & SD & average & SD & average & SD & average & SD \\
\hline BMI & 16.1 & 1.4 & 16.1 & 1.3 & 16.4 & 1.6 & 16.2 \\
\hline A.INDEX & 2.7 & 0.7 & 2.4 & 0.4 & 2.9 & 1 & 2.6 \\
\hline
\end{tabular}


Table 4.The comparison of average triglyceride, total cholesterol, LDL, VLDL and HDL cholesterol values between the groups

\begin{tabular}{|c|c|c|c|c|c|c|c|}
\hline & \multicolumn{2}{|c|}{ Group 1} & \multirow{2}{*}{$\begin{array}{l}\text { Group } 2 \\
\text { average }\end{array}$} & \multirow[b]{2}{*}{ SD } & \multicolumn{2}{|c|}{ Control } & \multirow[b]{2}{*}{$\mathbf{p}$} \\
\hline & average & SD & & & average & SD & \\
\hline TG & 92.1 & 42.6 & 117.6 & 74.1 & 98.5 & 42.9 & $\mathrm{p}>0.05$ \\
\hline T.CHOLESTEROL & 164.5 & 54 & 143.6 & 36.7 & 157.3 & 33 & $\mathrm{p}>0.05$ \\
\hline LDL & 96.8 & 28.6 & 62.7 & 22.2 & 86.9 & 28.8 & $\mathrm{p}<0.05^{*}$ \\
\hline VLDL & 21.9 & 14.5 & 23.5 & 14.7 & 19.6 & 8.7 & $\mathrm{p}>0.05$ \\
\hline HDL & 47.6 & 15.6 & 51.4 & 14 & 50.6 & 13.5 & $\mathrm{p}>0.05$ \\
\hline
\end{tabular}

Table 5. Comparison of BMI and AI between the groups.

\begin{tabular}{|l|c|c|c|c|c|c|}
\hline & Group 1 & & Group 2 & & \multicolumn{2}{|c|}{ Control } \\
\hline & average & SD & average & SD & average & SD \\
\hline BMI & 16.8 & 1.7 & 17.6 & 3.6 & 21.2 & 3.8 \\
\hline A.INDEX & 4 & 2.3 & 2.7 & 0.8 & 3.2 \\
\hline
\end{tabular}

GH deficient 38 children and lipid values were searched in the first and the third years. Pre-treatment increased LDL cholesterol and apolipoproteinB levels became normal at the end of 3 years. Though apoA1 which is the major protein component of HDL cholesterol had a tendency to decline when compared to control group, no significant difference was observed [3].

It is known that hyperglycemia and insulin resistance are two important factors increasing cardiovascular risk. It is thought that the opposite effects of GH and IGF-1 on lipid metabolism balance each other. It was shown that $\mathrm{GH}$ positively affected 10 annual height increase in short stature normal children but did not change lipid metabolism [12-14]. There are some researches indicating the relationship between android type lipid distribution and hypertension, diabetes mellitus, stroke and myocardial infarction. In a survey GH was given for 1 year to GH deficient 27 children. There wasn't significant change in total cholesterol and HDL cholesterol, atherogenic index significantly decreased and apolipoproteinCIII which inhibits apolipoproteinCII and lipoprotein lipase increased $[14,15]$.

In a similar survey 12 patients treated for 9 months, HDL cholesterol increased significantly, total cholesterol didn't change and atherogenic index decreased until 5 months $[4,16]$. In a survey in which 17 children were followed for 3 years atherogenic index decreased and apolipoproteinA1 which is the main apolipoprotein of HDL cholesterol decreased also. In a similar study 1 year GH treatment positively affected lipid profile $[17,18]$.

In our study in the first group treated with GH after 18 months of treatment there was no statistically significant difference between beginning, 6th month, 12th month and 18th month values of triglyceride, total cholesterol, LDL cholesterol, VLDL cholesterol, HDL cholesterol, BMI and atherogenic index $(p>0.05)$. There was only statistically significant difference between height increase in the first 6 months and second 6 months. The height increase in the first 6 months decreased from $5.6 \mathrm{~cm}( \pm 1.52)$ to $3 \mathrm{~cm}( \pm 1)$. This situation showed that height increase is more prominent in the initial phase of treatment. This was consistent with the catch-up growth. In our study we found that lipid profile didn't change significantly after 18 months treatment.

According to the beginning values of triglyceride, total cholesterol, VLDL cholesterol, HDL cholesterol and atherogenic index there was no statistically significant 11 difference between the 3 groups. In the LDL cholesterol level comparison, it was observed that average LDL cholesterol level of the second group, which is formed by the 20 patients to whom GH treatment had newly begun, is statistically significantly lower than the other two groups $(\mathrm{p}<0.05)$

As a result the effects of $\mathrm{GH}$ on lipid profile are controversial. In our study we investigated the effects of GH on lipid profile for a period of 18 months. For all the parameters at the beginning and 18th month values there was no statistically significant difference in between $(\mathrm{p}>0.05)$. Only in the first group average height increase in the first 6 months decreased from $5.6 \mathrm{~cm}( \pm 1.5)$ to $3 \mathrm{~cm}( \pm 1)$ in the second 6 months and this was statistically significant.

In the comparison of the second group with the first group only average LDL cholesterol level was low and this was statistically significant $(\mathrm{p}<0.05)$. In the comparison of the lipid parameters of the control group with the patient group there was no statistically significant difference in between.

\section{Acknowledgements}

I primarily thank all the physicians of Ankara Training and education hospital pediatrics clinic for their collaboration and support during my specialty education and also to my wife Havva AKMAZ ÜNLÜ for her help and patience and Dr. Kazım KARA for especially his guidance in biostatistics of the study.

\section{References}

1. (2001) Critical evaluation of the safety of recombinant human growth hormone administration: statement from the Growth Hormone Research Society. $J$ Clin Endocrinol Metab 86: 1868-1870. [Crossref]

2. Nilsson AG, Svensson J, Johannsson G (2007) Management of growth hormone deficiency in adults. Growth Horm IGF Res 17: 441-462. [Crossref]

3. De Muinck Keizer-Schrama S, Rikken B, Hokken-Koelega A, Wit JM, Drop S (1994) Comparative effect of two doses of growth hormone for growth hormone deficiency. The Dutch Growth Hormone Working Group. Arch Dis Child 71: 12-18. [Crossref]

4. Kohno H, Ueyama N, Yanai S, Ukaji K, Honda S (1995) Beneficial effect of growth hormone on atherogenic risk in children with growth hormone deficiency. J Pediatr 126: 953-955. [Crossref]

5. Underwood LE, Van Wyk JJ (1992) Normal and aberrant growth, In: Wilson JD, Foster DW (Eds), Williams Textbook of Endocrinology, Philadelphia: WB Saunders (8thedn), 1992: 1079-1120.

6. Goodman HM, Schwartz Y, Tai LR, Gorin E (1990) Actions of growth hormone on adipose tissue: possible involvement of autocrine or paracrine factors. Acta Paediatr Scand Suppl 367: 132-136. [Crossref] 
7. Wabitsch M, Heinze E (1993) Body fat in GH-deficient children and the effect of treatment. Horm Res 40: 5-9. [Crossref]

8. Green H, Morikawa M, Nixon T (1985) A dual effector theory of growth-hormone action. Differentiation 29: 195-198. [Crossref]

9. Deplewski D, Rosenfield RL (1999) Growth hormone and insulin-like growth factors have different effects on sebaceous cell growth and differentiation. Endocrinology 140 : 4089-4094. [Crossref]

10. Møller N, Jørgensen JO (2009) Effects of growth hormone on glucose, lipid, and protein metabolism in human subjects. Endocr Rev 30: 152-177. [Crossref]

11. Møller A, Rasmussen LM, Thuesen L, Christiansen JS (1989) Impact of human growth hormone on plasma lipoprotein concentrations. Horm Metab Res 21: 207-209. [Crossref]

12. Azzarito C, Boiardi L, Zini M, Agosti A, Biacchessi M, et al. (1994) Short and longterm effects of growth hormone treatment on lipid, lipoprotein, and apolipoprotein levels in short normal children. Horm Metab Res26: 432-435. [Crossref]
13. Guler HP, Schmid C, Zapf J, Froesch ER (1990) Effects of insulin-like growth factor I in man. Acta Paediatr Scand Suppl 367: 52-54. [Crossref]

14. Hindmarsh PC, Brook CG (1987) Effect of growth hormone on short normal children Br Med J (Clin Res Ed) 295: 573-577. [Crossref]

15. Hassan HM, Kohno H, Kuromaru R, Honda S, Ueda K (1996) Body composition, atherogenic risk factors and apolipoproteins following growth hormone treatment. Acto Paediatr 85: 899-901. [Crossref]

16. Schaefer GB, Greger NG, Fesmire JD, Blackett PR, Wilson DP, et al. (1994) Lipids and apolipoproteins in growth hormone-deficient children during treatment. Metabolism 43: 1457-1461. [Crossref]

17. Boot AM, Engels MA, Boerma GJ, Krenning EP, De Muinck Keizer-Schrama SM (1997) Changes in bone mineral density, body composition, and lipid metabolism during growth hormone $(\mathrm{GH})$ treatment in children with $\mathrm{GH}$ deficiency. $J$ Clin Endocrinol Metab 82: 2423-2428. [Crossref]

18. Ciresi A, Amato MC, Criscimanna A, Mattina A, Vetro C, et al. (2007) Metabolic parameters and adipokine profile during $\mathrm{GH}$ replacement therapy in children with $\mathrm{GH}$ deficiency. Eur J Endocrinol 156: 353-360. [Crossref]

Copyright: (C2016 Süleyman Ersin ÜNLÜ. This is an open-access article distributed under the terms of the Creative Commons Attribution License, which permits unrestricted use, distribution, and reproduction in any medium, provided the original author and source are credited. 